\title{
Revitalizing Generosity Through Philanthropy Values and Outcome-Based Education Islamic Religious Education Learning During the Covid-19 Pandemic
}

\author{
Izzatul Mardhiah $^{1}$, Amaliyah $^{2}$, Andy Hadiyanto $^{3}$, Ahmad Hakam $^{4}$, Endang Mintarja \\ \{izzatul-mardhiah@unj.ac.id', amaliyah@unj.ac.id², andy-hadiyanto@unj.ac.id ${ }^{3}$, ahmad- \\ hakam@unj.ac.id ${ }^{4}$, endang-mintarja@uin-jkt.ac.id $\left.{ }^{5}\right\}$
}

Universitas Negeri Jakarta ${ }^{1,2,3,4}$, Universitas Islam Negeri Syarif Hidayatullah Jakarta

\begin{abstract}
This study aims to describe the revitalization of generosity through the internalization of philanthropic values and strengthen learning experiences that have implications for the community's interests. During the COVID-19 pandemic, people tend to expect social assistance from other parties to survive. Therefore, it is necessary to revitalize the generosity of students because they are part of them, especially during the COVID-19 pandemic. Strengthening this character needs to be done because social goodness has psychological and religious elements. The psychological approach motivates attention and enthusiasm for work. The religious aspect motivates awareness to obey in carrying out God's commands. This type of research is descriptive qualitative. Data were collected through questionnaires, documentation studies, and literature studies. The data were then analyzed using qualitative and quantitative analysis techniques. The results show that the revitalization of generosity for students was to use the internalization of the value of philanthropy in IRE learning based on psychological and religious approaches. In addition, the study explains the empowerment of students' philanthropic attitudes by strengthening philanthropic institutions, which are to access financial assistance and learning centers and services to educate the poor to be creative and innovative, especially after the COVID-19 pandemic.
\end{abstract}

Keywords: generosity; philanthropic value; outcome-based; pandemic covid

\section{Introduction}

Changes in human behavior are influenced by situations and conditions they faced. One of the problems currently being faced by the world community is Covid 19 pandemic. The covid19 pandemic causes health, economy (PH et al., 2020), and mental health crisis. The government and non-governmental organizations are trying to mitigate the negative impacts of the COVID-19 pandemic, one of which is by providing food, medical treatment, policies to prevent the wider spread of the virus, etc. However, these efforts can only solve problems that impact physically. The psychological impacts are neglected, so it may bring up major mental health crises. 
The attitude of caring for each other is one of the keys to reducing the socio-economic impacts. Even though some people experience bad financially, the Covid-19 pandemic does not cause a significant financial problem for some others. Encouraging generosity is necessary because it generates motivation to work for people who are helped, help others in difficulties, and is part of religious observance.

Through Islamic Religious Education (IRE), universities play an important role in forming generous attitudes of students to mitigate the impacts of the Covid-19 pandemic. The way to solve this is through the method and related tasks as learning outputs. Giving alms can indoctrinate the mind to realize that giving alms is a good deed that can lighten a person's burden. The affective benefit is happiness because alms can also improve mental health (Rini Julistia, 2020).

The study conducted by Suryaman (2020) found that the dominant factors can be developed as a process in empowering generosity and caring for others of students through IRE with an outcome-based education approach according to the curriculum 'free learning' program or Merdeka belajar. Factors that can empower social attitudes such as generosity can be seen in psychological factors whether someone is difficult or likes to be generous. The study of Hadiyanti (2008) shows that the internal factors that hinder empowerment are the lack of mutual trust, the lack of innovation or creativity skills, quitter, low aspirations, not being able to enjoy the results of work, the narrow insight of time. narrow, familism, very dependent on government assistance, very attached to the place of residence, and unable or unwilling to empathize (Hadiyanti, 2008).

Intrinsic and extrinsic motivation can tell how someone does social good. According to Festinger's theory of cognitive dissonance, changing attitude can be done by adding an attitude assessment component consisting of cognitive development (to know), affective (to feel), and conative (to act) (Nursandi, 2020). Moreover, generosity behavior can also be categorized with three main approaches: sociological, psychological, and multidimensional (Hassan et al., 2018).

In this study based on the cognitive dissonance theory, the encouragement of generous attitudes considers several aspects: psychological aspects, cognitive aspects, and environmental aspects. To find out the proper process and form of encouragement according to the characteristics of students based on these situations and conditions, there are several research questions to answer: what factors need to be developed to encourage a generous attitude, how to encourage students to have that attitude, and what model of assignment or outcome-based IRE learning that suits their interests. So, the outcomes can revitalize the attitude of generosity.

\section{Research Method}

This study applied a qualitative and quantitative research approach. The data were collected using questionnaires, library research, and documentation. The researchers used the snowball sampling technique and resulted in 91 respondents from three universities: the State University of Jakarta, the Indonesian Education University, and the Ahmad Dahlan Institute of Technology and Business Jakarta. This study was conducted from June to August 2021.

\section{Discussion}




\subsection{Potential and Empowering Factors of Student Generosity During the Covid-19 Pandemic}

This study explores various factors and motivations that encourage students to be generous. The choice of motivation can be more than one factor according to the actual situation.

\section{a) Religious Factors}

This study showed that religion was the most dominant factor compared to other factors that encourage students to be generous. Table 1 presents factors that encourage students to be generous.

Table 1. Students' motivation to be generous

\begin{tabular}{llc}
\hline No & \multicolumn{1}{c}{ Motivation } & Percentage (\%) \\
\hline 1 & Religious Order & 69,2 \\
2 & Kinship/Friendship & 58,2 \\
3 & Hoping to be helped in the future & 47,3 \\
4 & Feeling sorry & 45,1 \\
5 & Imitating others & 30,8 \\
6 & Empathy and sympathy & 1,1 \\
7 & Self-motivated/voluntary & 1,1 \\
8 & Feeling happy & 1,1 \\
\hline
\end{tabular}

Theoretically, to encourage generosity is influenced by various factors: religious, psychological, sociological, etc. In this study, $69 \%$ of the respondents said that they were generous because of religious orders, $45,1 \%$ of the respondents said that they were generous because of feeling pity, and $58 \%$ of the respondents said that they were generous because they had a relationship with the people they helped. However, this study also showed that generosity had not become a prominent character because only $1,1 \%$ of the respondents said that they were generous because of empathy and sympathy, and only $1,1 \%$ of the respondents said that they were generous because of self-motivated/voluntary. Most of them said because of religious orders which ideally integrated as personal characters.

To be generous because of self-motivated/voluntary should be scored higher than other motivation. It was scored lower than kinship/friendship (58.2\%), hoping to be helped in the future $(47.3 \%)$, imitating others $(30,8 \%)$, or obligations as a member of a social organization $(24,2 \%)$. This can happen because, so far, people do it. After all, it is an obligation as religious people. IRE focuses on the development of the cognitive domain. Balihar Sanghera in his research also finds that most of his research respondents with dominant reflexivity show that charity is useful for achieving practical things that are important for their welfare. Moral individualism is a prominent feature of their consideration of giving (Sanghera, 2017).

These findings become the basis for utilizing religious factors with several strategies to strengthen the psychological aspect so that people are generous because of their own will. This finding is in line with other research that found that religious belief affects Chinese college students' charitable giving and volunteering (Xie et al., 2020), and other studies that religiosity, altruism, and personal satisfaction were identified as the three most important factors (Opoku, 2013).

\section{b) Students' Interest in Social Activities on Campus}


Another way to encourage students' generous attitude is by strengthening social organizations in the university. Altruism and personal satisfaction are identified as the three most important factors that encourage someone to engage in charitable behavior. Psychologically, teenagers like to make friends by participating in activities such as social action. They even prefer to plan an event by themselves than just attend as a participant. Usually, social events that involve teenagers become more creative and innovative than activities held by other parties. The following are the students' responses to the facilities that they need to encourage a generous attitude.

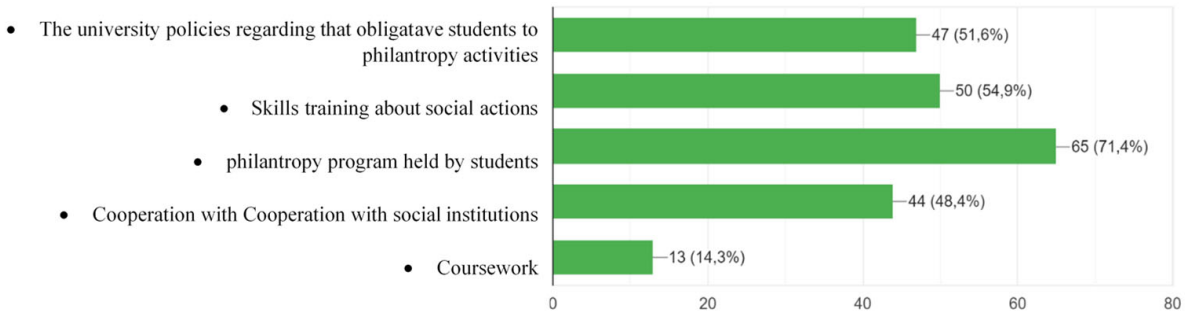

Fig. 1. The Facilities Supporting the Student's Generosity

The data showed that they prefer philanthropy programs that they organize themselves $(71,4 \%)$ than direct policies from the university $(51,6 \%)$, collaboration with other institutions (48.4\%), or Although $14.3 \%$ of respondents chose college assignments to encourage the generous attitude, IRE can support that.

\section{c) The Model of Student Philanthropy Program}

To encourage a generous attitude, students also need to explore their potential and interest in the model of activities they undertake. The following are the students' responses to the kinds of activities that can encourage a generous attitude.

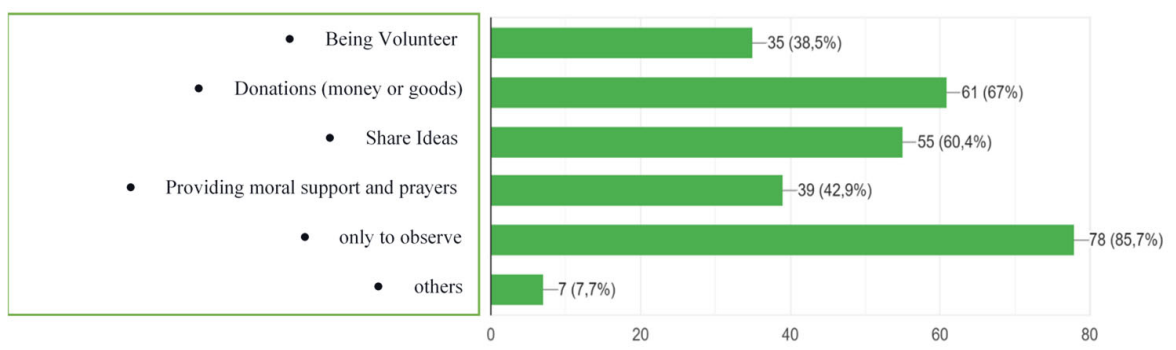

Fig. 2. The Model of Student Philanthropy Activities

Not only in Indonesia, but several universities in other countries also made student philanthropy programs. For example, at Northern Kentucky University (NKU), more than 2,000 students have participated in the direct giving model of student philanthropy in at least 40 different courses. In addition to direct giving, there is at least one other model of student philanthropy that has emerged in the past two years or so that is the "indirect giving" model 
partners a class with a corporation or foundation in the "real world" (Millisor \& Cencula Olberding, 2009).

In this study, students showed their generous attitudes in various forms. Most of them gave moral support and prayer. This happens because most of them have not earned money so giving moral support and prayer is a minimal action to show that they care to others. It is pretty encouraging that $67 \%$ have been involved in social actions in donations of money or goods. Some of them even started to being volunteers (38.5) or even gave ideas for social action $(60.4 \%)$, as we often see on the street, and started to get involved in the social program $(42.9 \%)$. However, unfortunately, among them $(7.7 \%)$ only observed nothing kind of social action.

\section{d) Use Of Social Media to Encourage A Generous Attitude}

Today, people share their ideas on social media. People also can use social media to encourage a generous attitude. Based on the data obtained through the questionnaire, most students chose social media to share information about philanthropy projects $(90.1 \%) .30,8 \%$ of them chose to convey ideas directly to social institutions. $17.6 \%$ of them formulated a proposal. This is an achievement and can be used as an idea of assignment in IRE class.

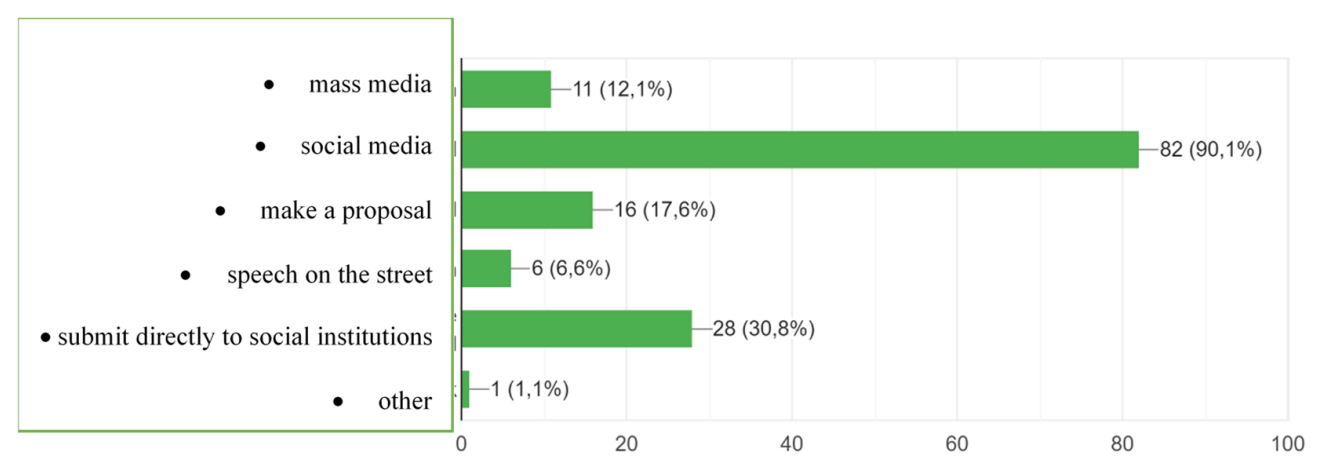

Fig. 3. How Student Shares Information about Philanthropy Projects

\subsection{The Process of Encouraging Generous Attitudes Through IRE}

The formation and development of a charitable attitude to students on religiosity and psychological factors. These factors serve as a tool to revitalize and empower students' generosity.

\section{a) Encouraging generous attitude through Religious and Psychological Aspects}

Encouraging generous attitudes through psychological aspects can be done internally and externally. For example, the university provides opportunities for students to choose the social activities they are most interested in. IRE as one of the courses in higher education is obliged to encourage students to be generous. It is necessary to internalize philanthropic values in IRE class such as improving students' achievement in the affective domain, empowering students to have self-awareness, and implementing generosity attitudes. Students can participate in a volunteering program, lecturers give assignments to students to participate in programs 
conducted by social institutions, in the form of ideas about developing zakat institutions or social institutions, as for the search for interest in the form of social action revealed in diagram IV, which shows the findings among them have started to get involved and enjoy volunteering $(38,5)$.

Some have taken the initiative to provide ideas for social action $(60.4 \%)$ or are involved in a general social activity (42.9\%). These forms of social action that they usually do can be appreciated and at the same time become a bill from IRE learning so that the skill and affective domains can be character among students, not just some of them.

The revitalization of generosity in students by internalizing and regulating IRE learning through social activities is reinforced by previous research, which states that someone does something positive because of fear of God's punishment. culture of shame, Fear to God, i.e., 1) religious doctrine in the form of conviction requires one to carry out God's commands, 2) belief in God always influences human behavior and actions anytime and anywhere, 3) belief in asking for help from God (praying) can refrain themselves from behaving negatively (Mardhiah et al., 2021)).

\section{b) Strengthening Social and Community Aspects}

They are strengthening religious understanding and the benefits of alms or sharing with others in the study of Islamic perspectives. Encouraging students to be generous can be done by asking their opinions about how they provide care, the media to share information about philanthropy projects, and the most favorite forms of caring.

Students are more active and enjoy social activities that they plan themselves in an organization. It means encouraging students to be generous can be done by conducting more social programs on campus. This idea is the most effective way to encourage students to be generous. Students can participate in a social program even though they are not members of any social organizations or are not doing campus assignments. They are consciously willing to participate in social activities.

Based on the data above, $90.1 \%$ of students share information about philanthropy projects on social media, and $6.6 \%$ of them conduct speeches on the streets. It means today's youth prefers sharing ideas on social media such as Instagram, Facebook, etc. to sharing ideas through non-online actions. It also means that social media posts can be a form of effective assignment. Social media in IRE can be either instructional media or assignments.

Based on the data obtained from the questionnaire, $94.5 \%$ of students said that they help according to their abilities, and $25.3 \%$ of students recommend seeking help. It indicates that their self-confidence is very high. Therefore, they must develop their self-confidence by equipping and actualizing one's potential through knowledge literacy and strengthening skills as capital to contribute to communities in need. The following is an example of a design for the revitalization stage of developing a generous character through IRE learning with an outcomes-based approach. 


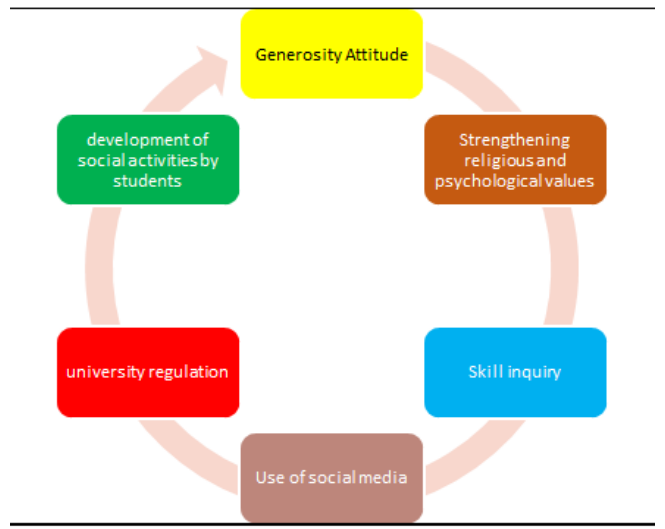

Fig. 4. The Process of Empowering Student Generosity

Based on the model, IRE learning with an outcome-based approach can be done through contextual learning by giving more project assignments. The findings are from students' interest $(65.9 \%)$ and conducting case studies in disaster areas $(45 \%)$. The survey results are in line with the demands for outcomes-based learning (as in diagram V). With several supporting tasks such as being involved in social activity reports (81.3\%) (see diagram VI).

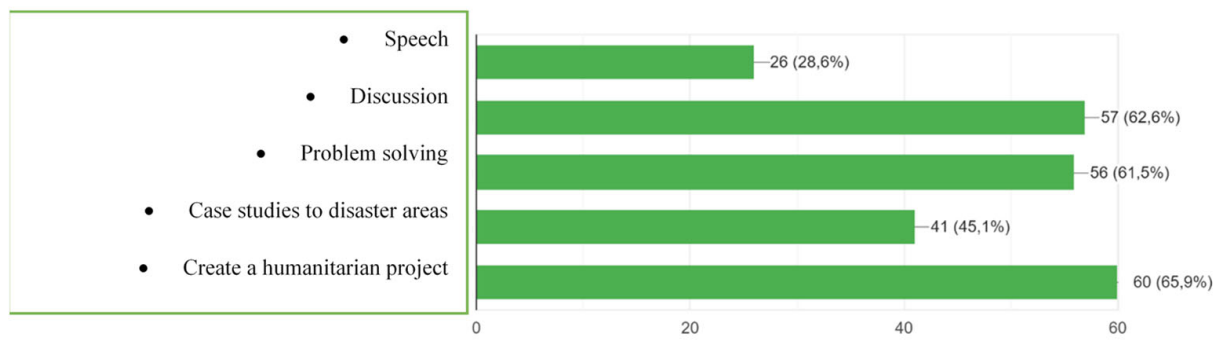

Fig. 5. Learning Methods That Support Generosity

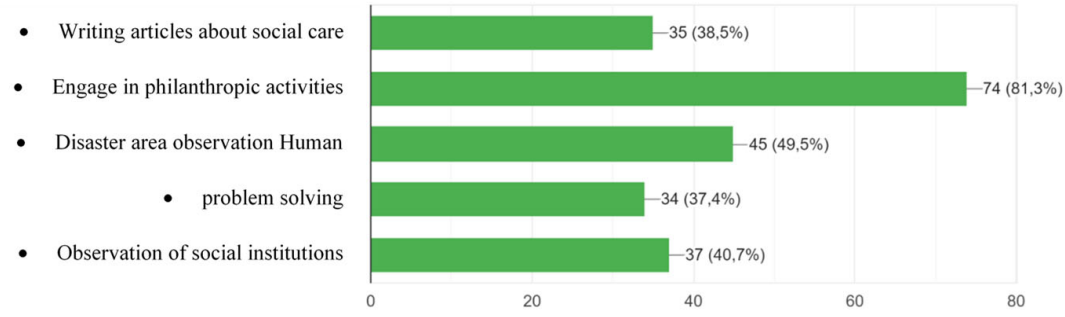

Fig. 6. IRE Learning Assignments Supporting Generosity Attitude

c) Example of IRE Syllabus that Promotes Generous Attitudes with An Outcome-Based Approach 
Developing an attitude of generosity through IRE learning makes it possible to formulate an example of a lesson plan design below.

Table 2. IRE Syllabus that promotes generous attitudes with an outcome-based approach

\begin{tabular}{|c|c|c|c|c|c|}
\hline Domain & $\begin{array}{c}\text { Graduate } \\
\text { Learning } \\
\text { Outcomes } \\
\end{array}$ & Materials & $\begin{array}{l}\text { Learning } \\
\text { methods }\end{array}$ & Assignments & Assessments \\
\hline Cognitive & $\begin{array}{l}\text { Students can } \\
\text { classify the } \\
\text { concepts of } \\
\text { generosity }\end{array}$ & $\begin{array}{l}\text { Generosity } \\
\text { and Social } \\
\text { Concern in } \\
\text { Islamic } \\
\text { Studies }\end{array}$ & $\begin{array}{l}\text { Case-based } \\
\text { learning }\end{array}$ & $\begin{array}{l}\text { State of the art of } \\
\text { several concepts } \\
\text { explored at least five } \\
\text { journals and three } \\
\text { books }\end{array}$ & $\begin{array}{l}\text { Perform presentation } \\
\text { of the state-of-the-art } \\
\text { findings. } \\
\text { The assessment is the } \\
\text { rubrics }\end{array}$ \\
\hline $\begin{array}{l}\text { Psychomot } \\
\text { or }\end{array}$ & $\begin{array}{l}\text { Students can } \\
\text { demonstrate } \\
\text { skills in } \\
\text { designing } \\
\text { philanthropy } \\
\text { proposals }\end{array}$ & $\begin{array}{l}\text { Generosity } \\
\text { and Social } \\
\text { Concern in } \\
\text { Islamic } \\
\text { Studies }\end{array}$ & $\begin{array}{l}\text { Team-based } \\
\text { project } \\
\text { learning }\end{array}$ & $\begin{array}{l}\text { Philanthropy } \\
\text { proposals and } \\
\text { students present and } \\
\text { publish on social } \\
\text { media. }\end{array}$ & $\begin{array}{l}\text { Performances, } \\
\text { products. } \\
\text { Rubrics to assess the } \\
\text { proposal and the } \\
\text { process of making it as } \\
\text { well as uploading it on } \\
\text { social media }\end{array}$ \\
\hline Affective & $\begin{array}{l}\text { Students can } \\
\text { apply a } \\
\text { generous } \\
\text { attitude in } \\
\text { social } \\
\text { activities }\end{array}$ & $\begin{array}{l}\text { Generosity } \\
\text { and Social } \\
\text { Concern in } \\
\text { Islamic } \\
\text { Studies }\end{array}$ & $\begin{array}{l}\text { a) Contextual } \\
\text { learning, } \\
\text { b) visiting } \\
\text { disaster } \\
\text { c) Philanthrop } \\
\text { y action }\end{array}$ & $\begin{array}{l}\text { the video of } \\
\text { philanthropy } \\
\text { activities }\end{array}$ & $\begin{array}{l}\text { Portfolio of student } \\
\text { activities }\end{array}$ \\
\hline Conative & $\begin{array}{l}\text { Students can } \\
\text { show a } \\
\text { generous } \\
\text { attitude in } \\
\text { social } \\
\text { activities }\end{array}$ & $\begin{array}{l}\text { Generosity } \\
\text { and Social } \\
\text { Concern in } \\
\text { Islamic } \\
\text { Studies }\end{array}$ & $\begin{array}{l}\text { a) Contextual } \\
\text { learning, } \\
\text { b) visiting } \\
\text { disaster } \\
\text { c) Philanthrop } \\
\text { y action }\end{array}$ & $\begin{array}{l}\text { the video of } \\
\text { philanthropy } \\
\text { activities }\end{array}$ & $\begin{array}{l}\text { Portfolio of student } \\
\text { activities }\end{array}$ \\
\hline
\end{tabular}

\section{Conclusion}

The results show that the revitalization of generosity for students uses the internalization of philanthropic values in IRE learning based on psychological, religious approaches and adaptation to the development of digital media, namely social media, especially during the COVID-19 pandemic and the challenges of independent learning. Empowerment through revitalizing the skills aspect is the second component to strengthen students' expectations in meeting psychological needs. The strengthening of religious understanding is the foundation and the main component to strengthen the potential for affection, cognition, and conation of students. Another component that is empowered is campus regulation of student-initiated social activities. The IRE learning model with an outcome-based approach can optimize project methods, case studies, and observations with assignments in activity reports, written publications in social media, mass media, and journals.

\section{References}

[1] Hadiyanti, P. (2008). Strategi Pemberdayaan Masyarakat Melalui Program Keterampilan Produktif di PKBM Rawasari Jakarta Timur. Perspektif Ilmu Pendidikan 
- Vol. 17 Th. IX, 17(April).

[2] Hassan, S. H., Masron, T. A., Noor, M., \& Ramayah, T. (2018). Antecedents of trust towards the attitude of charitable organization in monetary philanthropic donation among generation-Y. Asian Academy of Management Journal, 23(1), 53-78. https://doi.org/10.21315/aamj2018.23.1.3

[3] Mardhiah, I., Amaliyah, Hakam, A., \& Hadiyanto, A. (2021). Developing environmental care attitudes among college students through Islamic education (IRE) learning with a humanist-contextual approach. IOP Conference Series: Earth and Environmental Science, 743(1). https://doi.org/10.1088/1755-1315/743/1/012004

[4] Millisor, J., \& Cencula Olberding, J. (2009). Philanthropy in Colleges and Universities. Academic Exchange Quarterly, 13(4), 11.

[5] Nursandi, I. (2020). Perubahan Sikap Sosial Anak Jalanan Pada Pkbm Himmata di. Jurnal Pendidikan Kewarganegaraan Undiksha, 18.

[6] Opoku, R. A. (2013). Examining the motivational factors behind charitable giving among young people in a prominent Islamic country. International Journal of Nonprofit and Voluntary Sector Marketing, 18(3), 172-186. https://doi.org/10.1002/nvsm.1457

[7] PH, L., Suwoso, R. H., Febrianto, T., Kushindarto, D., \& Aziz, F. (2020). Dampak Pandemi Covid-19 bagi Perekonomian Masyarakat Desa. Indonesian Journal of Nursing and Health Sciences, 1(1), 37-48.

[8] Rini Julistia, S. (2020). Kebahagiaan ditinjau dari Perilaku Bersedekah. Jurnal Psikologi Terapan [JPT], 5.

[9] Sanghera, B. (2017). Charitable giving and reflexive individuals: How personal reflexivity mediates between structure and agency. Social Science Information, 56(1), 28-48. https://doi.org/10.1177/0539018416646486

[10] Suryaman, M. (2020). Orientasi Pengembangan Kurikulum Merdeka Belajar. Seminar Nasional Pendidikan Bahasa Dan Sastra, 1(1), 13-28.

[11] Xie, F., Lu, Y. P., \& Zhang, Y. (2020). Does religious belief affect the volunteering and donating behavior of Chinese college students? Religions, 11(8), 1-11. https://doi.org/10.3390/rel11080403 